\title{
Spatial estimation of soil erosion using RUSLE modeling: a case study of Dolakha district, Nepal
}

\author{
Pawan Thapa* (iD
}

\begin{abstract}
Background: Soil erosion causes topsoil loss, which decreases fertility in agricultural land. Spatial estimation of soil erosion essential for an agriculture-dependent country like Nepal for developing its control plans. This study evaluated impacts on Dolakha using the Revised Universal Soil Loss Equation (RUSLE) model; analyses the effect of land use and land cover (LULC) on soil erosion.

Results: The soil erosion rate categorized into six classes based on the erosion severity, and 5.01\% of the areas found under extreme severe erosion risk (> $80 \mathrm{Mg} \mathrm{ha}^{-1}$ year ${ }^{-1}$ ) addressed by decision-makers for reducing its rate and consequences. Followed by $10 \%$ classified between high and severe range from 10 to $80 \mathrm{Mg} \mathrm{ha}^{-1}$ year ${ }^{-1}$. While $15 \%$ and $70 \%$ of areas remained in a moderate and low-risk zone, respectively. Result suggests the area of the north-eastern part suffers from a high soil erosion risk due to steep slope.

Conclusions: The result produces a spatial distribution of soil erosion over Dolakha, which applied for conservation and management planning processes, at the policy level, by land-use planners and decision-makers.
\end{abstract}

Keywords: Soil erosion, Land cover, Land use, Mountainous region, Topography

\section{Background}

Last few decades, soil erosion impacts natural resources and agricultural production globally (Bakker et al. 2005; Pimentel et al. 1995; Prasannakumar et al. 2012). In Mountain regions, soil erosion causes severe hazards, such as heavy rainfall, surface water flow on bare lands that contribute to land degradation (Ristić et al. 2012; Ashiagbor et al. 2013; Tamene and Vlek 2008). The primary soil erosion is onsite consequences impacts on soil fertility loss and degradation of soil resources quality, whereas pollution on water bodies and settling sediments are an offsite (Morgan et al. 1984; Blaikie and Brookfield 2015). It directly impacts on the environment, economy, and agriculture in mountain areas (Vanacker et al. 2003; Navas et al. 2004). Its rate increased through the change

\footnotetext{
*Correspondence: pawan.thapa@ku.edu.np

Department of Geomatics Engineering, Kathmandu University, Dhulikhel, Nepal
}

in precipitation and temperature pattern and eventually altering the runoff and land use, which causes flood, drought, and famine (Nearing et al. 2004; Thapa and Dhulikhel 2019; Zhao et al. 2013). On the other hand, the deposition of sediments on the river affects reservoir and dams, increases their costs of maintenance, and in the long run, makes them unusable (Samaras and Koutitas 2014). There have been several studies to understand this situation; their findings control soil erosion and ecological restoration (Samaras and Koutitas 2014; Shah et al. 1991). Although some attention regarding erosion modeling essential for inaccessible mountainous areas.

Mountain region is highly vulnerable to resource degradation caused by landslides, soil loss from steep slopes, and deforestation (TolIIrism 1995). In Nepal, approximately $45.5 \%$ of land erodes from the water in steeper areas (Chalise et al. 2019). One study shows that soil loss of agricultural land in the hills through surface erosion, other finds in 1992 and 1993 of Likhu Khola watershed 
soil loss and slightly degraded secondary forest (Shrestha 1997; Gardner and Jenkins 1995). Several models exist for prediction of soil erosion from empirical (USLE/RUSLE), and considerably varies in its data input. The RUSLE represents raindrop impacts on climate, soil, topography, and land use affect rill and inter rill soil erosion (Magdoff and Weil 2004). This method is widely used to estimate soil erosion loss and risk, which provides a guideline for the development of conservation plans and controlling erosion under different land-cover conditions, such as croplands, rangelands, and disturbed forest lands (Milward and Mersey 1999). The remote sensing and GIS techniques are feasible for soil erosion estimation and spatial distribution in larger areas (Milward and Mersey 1999; Bahadur 2012). The remote sensing, GIS, and RUSLE provide the potential to estimate soil erosion loss on a cell-by-cell basis (Milward and Mersey 1999). The RUSLE model with GIS used for estimation of the spatial distribution of soil erosion in Dolakha; however, the model is applicable only in the prediction of sheet and rill erosion, unable to estimate the rate of gully erosion (Wang et al. 2002). It provides a framework for decisionmakers for planning activities to control erosion and contributes toward filling a gap of soil loss information of a particular district.

\section{Materials and methods}

\section{Study area}

The study area is the Dolakha District, Nepal, situated in the northeast part of Kathmandu (Fig. 1; Dennison and Rana 2017). It's fragile in the last few years for soil erosion, deforestation, and terrace farming on steep slopes and rapid population pressure on natural resources (Thapa and Upadhyaya 2020; Pei and Sharma 1998). Other significant contributors are land use and land cover change caused by a human that increases the erosion rate here (Fall et al. 2011).

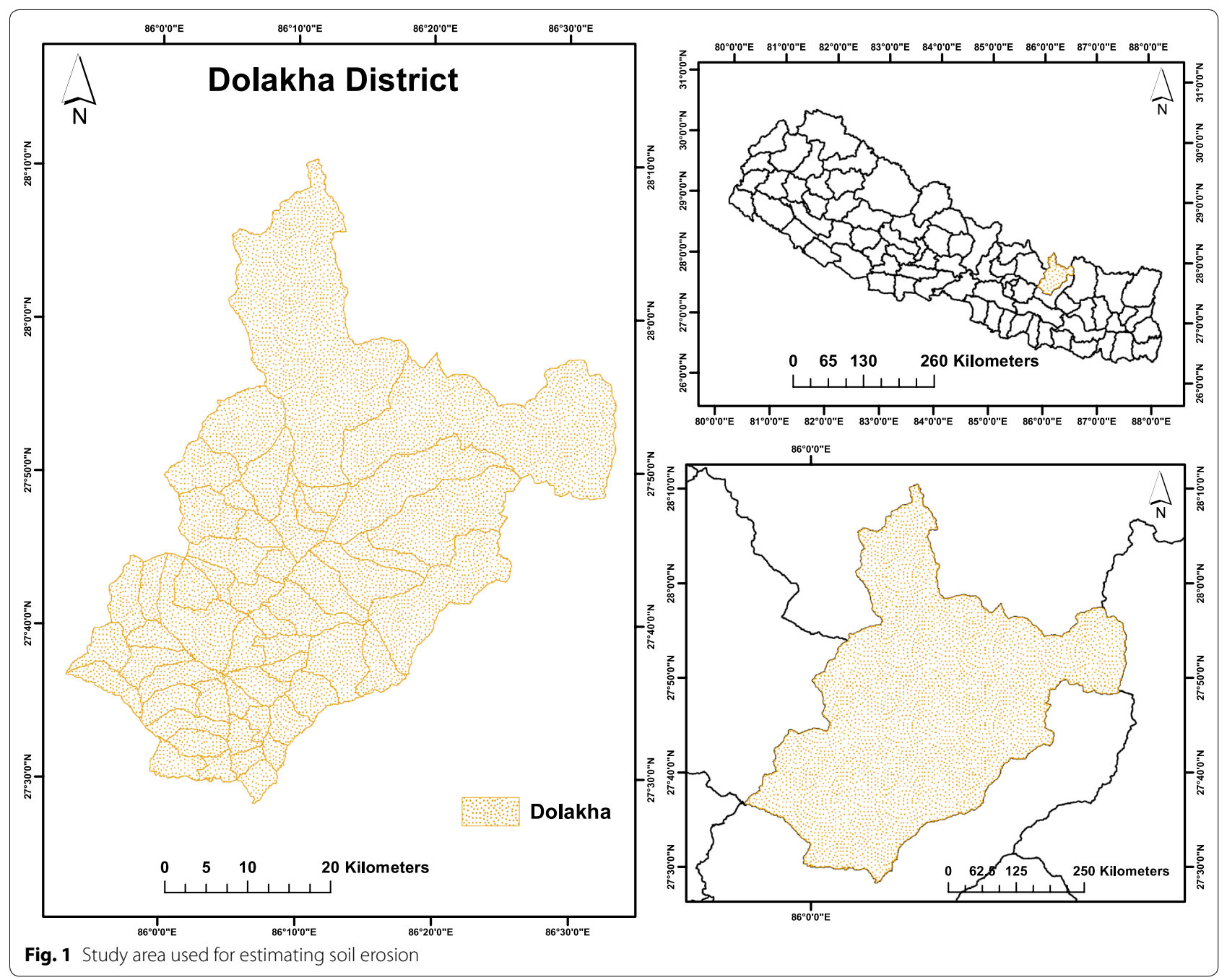




\section{Data collection}

The spatial datasets for this research are shown in Table 1.

\section{Methods}

The RUSLE model estimates soil damage for ground slopes in Geographic Information System (GIS) platform (Yitayew et al. 1999; Fig. 2). A combined equation of geophysical and land cover factors to evaluate the yearly soil loss from a unit of property. It assesses erosion risk in the research area, which has its qualities and application scopes (Ciesiolka et al. 1995; Boggs et al. 2001). Its global model to predict soil loss because of its convenience and compatibility with GIS (Milward and Mersey 1999; Tang et al. 2015; Jha and Paudel 2010; Súri et al. 2002). GIS and remote sensing technology advancement

Table 1 The datasets used for the RUSLE modelling

\begin{tabular}{ll}
\hline Datasets & Data source \\
\hline DEM & SRTM DEM \\
& https://earthexplorer.usgs.gov/ \\
& A product of METI and NASA \\
Soil map & Digital soil map of the World (2019) \\
& www.fao.org/geonetwork/srv/en/metadata.show \\
& Produced by FAO-UNESCO (1:5,000,000 scale) \\
Landcover map & Landcover map of Nepal (2010) \\
& Produced by ICIMOD \\
Rainfall map & TRMM Data \\
& https://gpm.nasa.gov/?q=TRMM \\
& Produced by NASA \\
\hline
\end{tabular}

enabled a more accurate estimation of the factors used for calculation (TolIIrism 1995; Park et al. 2005; Ganasri and Ramesh 2016; Atoma 2018). Each of the elements derived separately in raster data format and the erosion calculated using the map algebra functions. Figure 2 illustrates the framework for the RUSLE model calculation and expressed by an equation,

$$
\mathrm{A}=[\mathrm{R}] *[\mathrm{~K}] *[\mathrm{LS}] *[\mathrm{C}] *[\mathrm{P}],
$$

where $\mathrm{A}=$ soil loss $\left(\mathrm{mg} \mathrm{ha}^{-1}\right.$ year $\left.^{-1}\right), \mathrm{R}=$ rainfall erosivity factor $\left(\mathrm{mm} \mathrm{ha}^{-1}\right.$ year $\left.^{-1}\right), \mathrm{K}=$ soil erodibility factor $\left(\mathrm{mg} \mathrm{ha}^{-1}\right.$ year $\left.^{-1}\right), \mathrm{LS}=$ slope-length and slope steepness factor (dimensionless), $\mathrm{C}=$ land management factor (dimensionless), and $\mathrm{P}=$ conservation practice factor (dimensionless).

\section{RUSLE parameters computation}

a. Rainfall erosivity factor (R)

This rainfall erosion factor $(\mathrm{R})$ describes the intensity of precipitation at a particular location based on their amount on soil erosion (Koirala et al. 2019; Thapa and Upadhyaya 2019). Essential for soil erosion risk assessment under future land use and climate change (Stocking 1984). It quantifies an effect of raindrop amount and rate of runoff associate with rainfall and its unit expressed in $\mathrm{mm} \mathrm{ha} \mathrm{h}^{-1} \mathrm{~h}^{-1}$ year $^{-1}$. During this study, the rainfall map produced by the National Aeronautics and Space Administration (NASA) used to generate a rainfall erosion factor (Wischmeier and Smith 1978). This map shows mean annual precipitation over the district, equation integrated to make the R-factor given by Morgan et al. (1984).

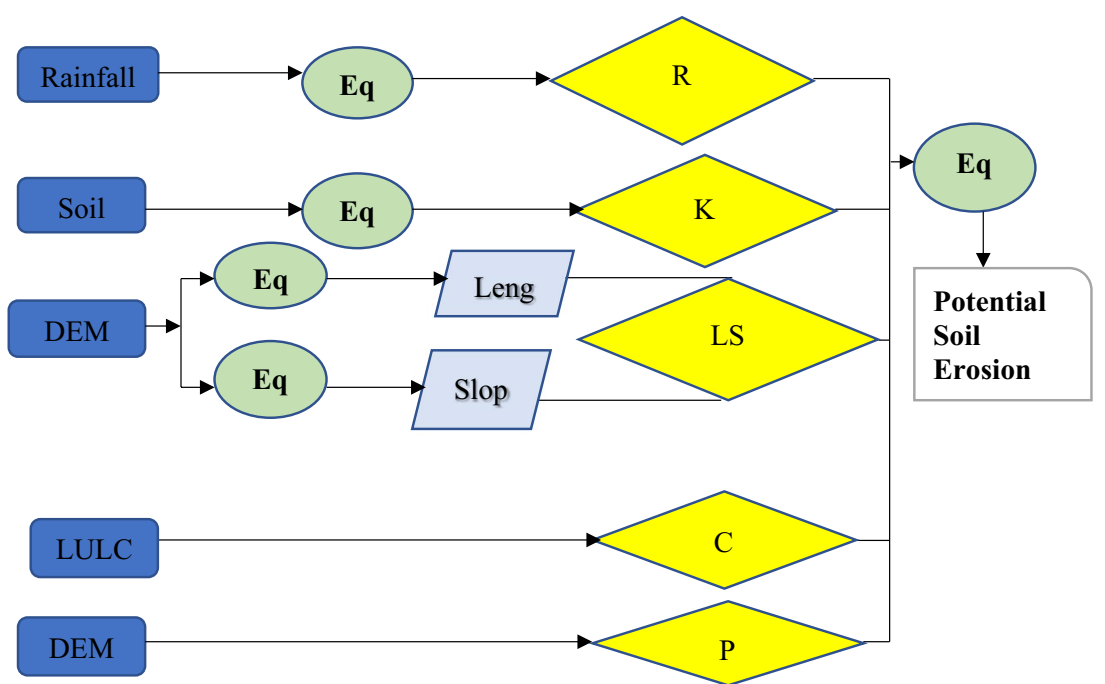

Fig. 2 The methodological framework for potential soil erosion using RUSLE model 


$$
\mathrm{R}=38.5+0.35 \mathrm{P},
$$

where $\mathrm{R}=$ rainfall erosivity factor, $\mathrm{P}=$ mean annual rainfall in $\mathrm{mm}$

\section{b. Soil erodibility factor (K)}

The soil erodibility factor (K) measures the susceptible soil types and their particles to detachment and transport by rainfall and runoff. The $\mathrm{K}$ factor influenced by soil texture, organic matter, soil structure, and permeability of the soil profile (Erencin et al. 2000). The equation provided by reference used to estimate the soil loss (Kouli et al. 2009).

$$
\mathrm{K}=\mathrm{Fcsand} * \mathrm{Fsi}-\mathrm{cl} * \text { Forgc } * \text { Fhisand } * 0.1317,
$$

where

$$
\begin{aligned}
& \text { Fcsand }=\left[0.2+0.3 \exp \left(-0.0256 \mathrm{SAN}\left(1-\frac{S I L}{100}\right)\right)\right] \\
& \text { Fsi-cl }=\left[\frac{S I L}{C L A+S I L}\right]^{0.3}, \\
& \text { Forgc }=\left[1.0-\frac{0.25 \mathrm{C}}{C+\exp (3.72-2.95 C)}\right] \\
& \text { Fhisand }=\left[1.0-\frac{0.70 \mathrm{SN} 1}{S N 1+\exp (-5.51+22.9 S N 1)}\right]
\end{aligned}
$$

where SAN, SIL and CLA are \% sand, silt and clay, respectively; $\mathrm{C}$ is the organic carbon content; and SN1 sand content subtracted from 1 and divided by 100. Fcsand =low soil erodibility factor for soil Fsi$\mathrm{cl}=$ low soil erodibility factor with high clay to silt ratio. Forgc $=$ factor that reduces soil erodibility for soil with high organic content. Fhisand $=$ factor that reduces soil erodibility for soil with high sand content.

\section{c. Topographic factor (LS)}

The topographic factor (LS) created from two subfactors: a slope gradient factor (S) and a slope-length factor $(\mathrm{L})$, both determined from the Digital Elevation Model (DEM). The slope-length and gradient parameter is crucial in the soil erosion modeling for calculating overland flow (surface runoff) (Morgan et al. 1992). The $L$ and $S$ represent the effect of slope length and steepness respectively on erosion, also when it increases soil loss per unit area rises. These calculated from the DEM and combined to result in the topographical factor grid using relation (Atoma 2018).

$$
\mathrm{L}=\left(\frac{\lambda}{22.13}\right)^{\mathrm{m}},
$$

where $\mathrm{L}=$ slope length factor, $\lambda=$ slope length $(\mathrm{m})$, $\mathrm{m}=$ slope-length exponent

$$
\begin{aligned}
& \mathrm{m}=\frac{F}{1+F^{\prime}}, \\
& \mathrm{F}=\frac{\sin / 0.0896}{3(\sin )_{0.8}+0.56},
\end{aligned}
$$

where $\mathrm{F}=$ ratio between rill erosion and inter rill erosion, $\beta=$ slope angle $\left(^{\circ}\right)$

In ArcGIS, L was calculated as,

$$
\text { flow }_{a c c}+625 \mathrm{~L}=\frac{\left(\text { flow }_{a c c}+625\right)^{(m+1)}-\text { flow }_{\text {acc }}^{(m+1)}}{25^{(\mathrm{m}+2)} * 22.13^{\mathrm{m}}},
$$

For slope gradient factor,

$$
\begin{aligned}
\mathrm{S}= & \operatorname{Con}((\operatorname{Tan}(\operatorname{slope} * 0.01745)<0.09), \\
& (10.8 * \operatorname{Sin}(\text { slope } * 0.01745)+0.03), \\
& (16.8 * \operatorname{Sin}(\text { slope } * 0.01745)-0.5),
\end{aligned}
$$

Final,

$$
\mathrm{LS}=\mathrm{L} * \mathrm{~S},
$$

d. Cover management factor $(C)$

The cover-management factor $(\mathrm{C})$ reflects the effect of cropping and other practices on erosion rates (Chalise et al. 2019). It's the most spatiotemporal sensitive as it follows plant growth and rainfall dynamics (Nearing et al. 2004). This factor defined as a non-dimensional number between zero and one representing a rainfall erosion weighted ratio of soil loss for specified land and vegetated conditions to the corresponding loss from continuous bare fallow (Wischmeier and Smith 1978). In this study, LULC produced by the ICIMOD used for preparing a C-factor map (Sheikh $\hat{A}$ et al. 2011). The raster map converted to polygon through raster to polygon tool and the attributes with the same land use type merged into a single class using ArcGIS 10.5 software, the study used eight types of land use (Table 2). Each land-use example, $C$ values assigned through reference ranges from 0 to 1 , where lower $C$ means no loss, while higher indicates uncover and significant chances of soil loss (Erencin et al. 2000; Panagos et al. 2015). 
Table 2 Cover management factor

\begin{tabular}{ll}
\hline Land use & C factor \\
\hline Forest & 0.03 \\
Shrubland & 0.03 \\
Grassland & 0.01 \\
Cultivated area & 0.21 \\
Barren land & 0.45 \\
water body & 0.00 \\
Snow Glacier & 0.00
\end{tabular}

Table 3 P factor values for slope (Kumar and Kushwaha 2013)

\begin{tabular}{ll}
\hline Slope \% & Contouring \\
\hline $0-7$ & 0.55 \\
$7-11.3$ & 0.60 \\
$11.3-17.6$ & 0.80 \\
$17.6-26.8$ & 0.95 \\
$>26.8$ & 1.00 \\
\hline
\end{tabular}

\section{e. Support practice factor $(\mathrm{P})$}

The support practice factor indicates the rate of soil loss according to agricultural practice. There are three methods, such as contours, cropping, and terrace, and vital elements to control erosion (Park et al. 2005). This contouring method used with $\mathrm{P}$ values ranges from 0 to 1 , where the value 0 represents proper anthropic erosion, and the value 1 indicates a non-anthropic erosion facility (Table 3, Kouli et al. 2009). It values for particular types of land cover used from published sources (Coughlan and Rose 1997; Yue-Qing et al. 2008).

\section{Potential erosion map}

The different data input processed in ArcGIS created fivefactor maps: R, K, LS, C, and P (Fig. 3). These raster maps integrated within the ArcGIS environment using the RUSLE relation to generate composite maps of the estimated erosion loss on the study area (Ganasri and Ramesh 2016; Atoma 2018). Zonal statistics tool and calculating geometry used for computing an area-weighted mean of the potential erosion rates for its generated to explore the relationship between slope and LULC on erosion (Bastola et al. 2019). The slope map of Dolakha created from DEM in ArcGIS and then reclassified into eight classes (Gorr and Kurland 2010).

\section{Results}

\section{Factor maps}

The results showed that the topographic factor (LS) value range between 0 and 12,073 (Fig. 3a); Rainfall erosivity factor (R) value ranges between 87.4938 and $1541.42 \mathrm{~mm} \mathrm{ha}^{-1}$ year $^{-1}$ (Fig. 3e); Soil erodibility factor $(\mathrm{K})$ value ranged from 0.2 to 0.32 (Fig. $3 \mathrm{~d}$ ). The support practice factor $(\mathrm{P})$ value for the entire area ranged from 0.55 to 1 (Fig. 3c). The cover management factor $(\mathrm{C})$ value ranged between 0 and 0.45 (Fig. $3 \mathrm{~b}$ ).

\section{Potential soil erosion rates of Nepal}

The potential soil erosion map of the Dolakha district produced multiplying the factor maps in ArcGIS (Fig. 4; Table 4). The soil erosion higher than $80 \%$ consists of a $5.01 \%$ area (Table 4 ). It shows that around $10 \%$ of high, very high, and severe risk zones need conservation to reduce the risk of soil erosion. The mean erosion rate high in barren lands, followed by agricultural lands, shrubs, grasslands, and forests, and the highest soil loss rates observed in steep slopes.

The study area classified into six classes that remained constant in the different erosion classes shown bold in the diagonal cells. Greater than $80 \%$ of the study area remained in the high severe erosion risk class. The proportion area at low and moderate risk of erosion is $70 \%$ and $15 \%$, respectively, while the space between the upper and very severe, around 15\%, indicates a chance increasing.

\section{Discussion}

RUSLE is an empirical-based modeling approach that predicts the long-term average annual rate of soil erosion on slopes using five factors. It estimates soil loss with similar terrain and meteorological conditions (Prasannakumar et al. 2012). This research, a potential soil erosion rate map of Dolakha generated using different sources (Table 1) for the RUSLE model using ArcGIS software. Its the first time that such an approach to assess erosion risk across an entire mountainous region, and the methodology still has certain limitations. Again, it identifies priority areas for reducing soil erosion. Other research studies having similar geographic characteristics also used the same method (Prasannakumar et al. 2012; Panagos et al. 2015; Kumar and Kushwaha 2013). In an erosion model, proper consideration of R-factor, LS-factor, K-factor, P-factor, and C-factor should minimize the uncertainties. The LS-factor with a maximum slope in the study area used as original RUSLE formulations ( $\mathrm{McCool}$ et al. 1989). According to the many research results, Nepal is vulnerable to soil erosion hazards due to five major factors, high annual precipitation, the soil characteristics, mainly texture and steep slopes, land covers, and soil conservation practices along the slopes ( $\mathrm{McCool}$ et al. 1987, 1989). Its total soil erosion is comparatively higher than in other countries of the world (Koirala et al. 2019). This study also found that around $15 \%$ of the total area in 


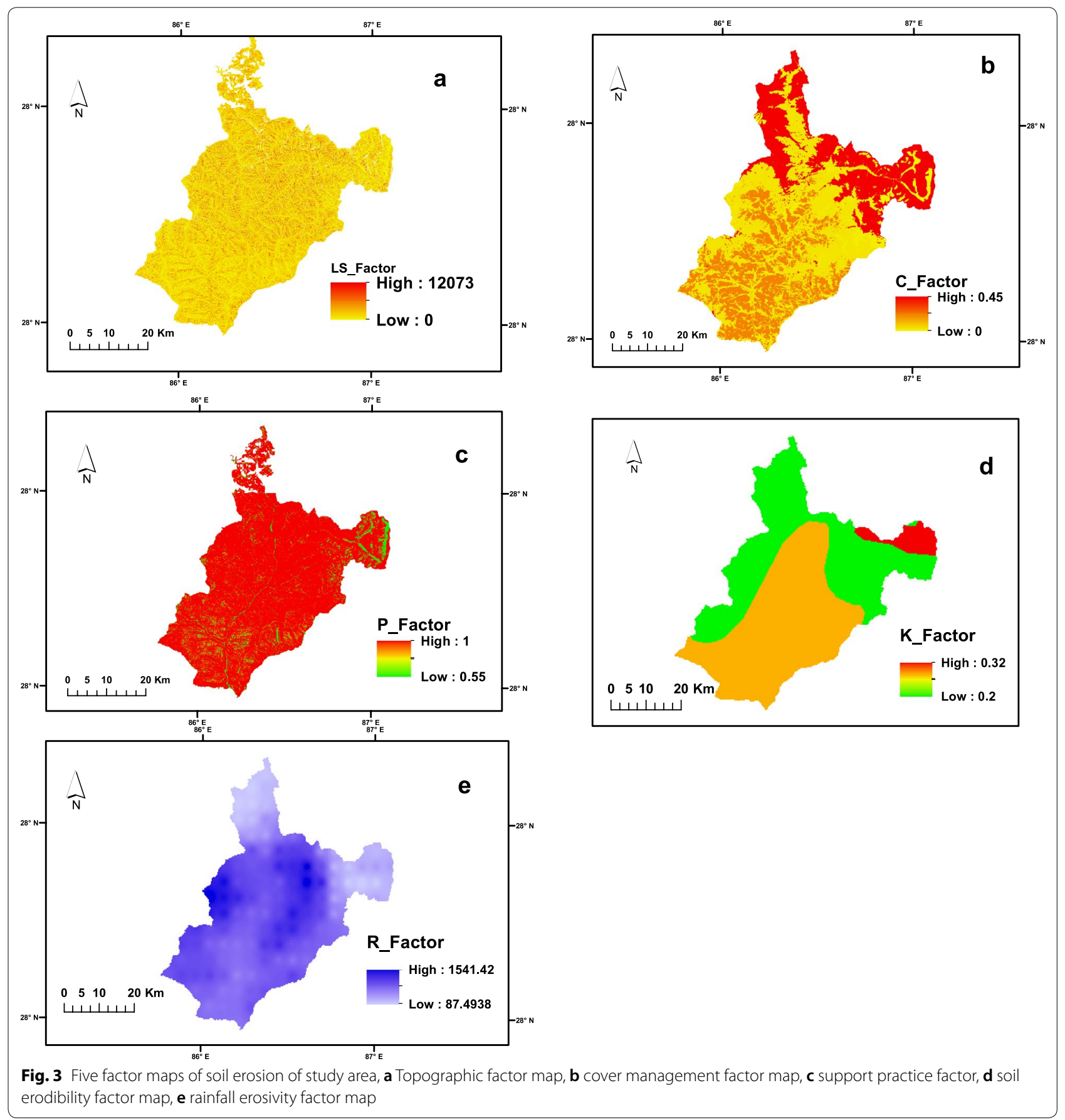

district was between upper and very severe region, which is common in rates of erosion of countries like India, Ethiopia, United Kingdom, Europe, and Africa in their steeper slope area (Morgan et al. 1984; Stocking 1984; Wischmeier and Smith 1978). Here, the suggested range of erosion is almost equal to that of Australia, China, as estimated by Lu et al. (2003). The higher erosion rates in China and Australia indicate the vulnerability to an erosion of the semi-arid and semi-humid areas of the world (Suárez de Castro and Rodríguez Grandas 1962). The soil erosion rates in the mountainous regions, like Nepal, also 


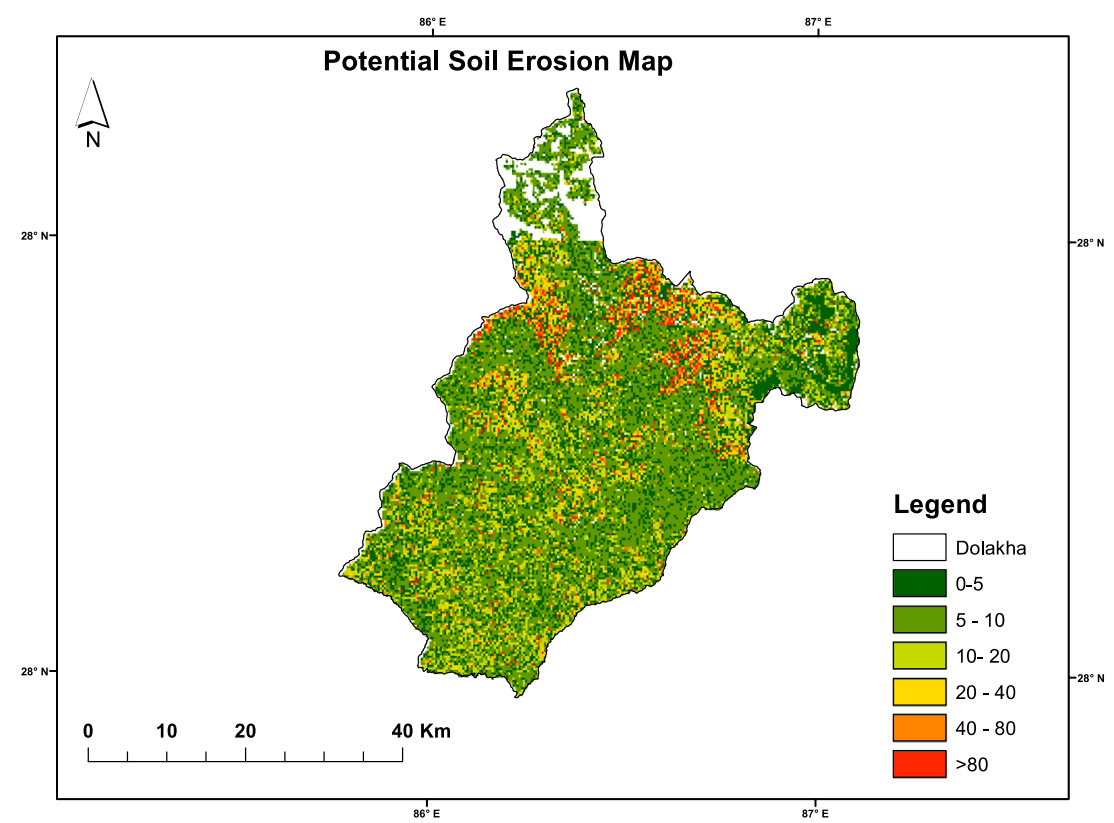

Fig. 4 Potential map of soil erosion rate of Dolakha district

Table 4 Potential soil erosion rate of Dolakha district

\begin{tabular}{|c|c|c|c|c|}
\hline Class & $\begin{array}{l}\text { Rate of erosion } \\
\left(\mathrm{Mg} \mathrm{ha}^{-1} \text { year }^{-1}\right)\end{array}$ & Area $\left(\mathrm{km}^{2}\right)$ & $\begin{array}{l}\text { Percentage } \\
\text { of area }\end{array}$ & Severity \\
\hline 1 & $0-5$ & 1730.105 & 70.01 & Low \\
\hline 2 & $5-10$ & 249.429 & 15.40 & Moderate \\
\hline 3 & $10-20$ & 28.327 & 2.41 & High \\
\hline 4 & $20-40$ & 2.937 & 4.15 & Very high \\
\hline 5 & $40-80$ & 0.446 & 3.02 & Severe \\
\hline 6 & $>80$ & 0.157 & 5.01 & Very severe \\
\hline
\end{tabular}

rise with an increase in slope (Assouline and Ben-Hur 2006).

RUSLE is the most commonly applied soil loss estimation model (Mekelle 2015; Wang et al. 2013; Maetens et al. 2012; Erol et al. 2015). Moreover, RUSLE model strength lies in giving predicted soil loss using limited information, especially in developing countries where data are scarce (Tadesse 2016; Shahid 2013; Angima et al. 2003) although RUSLE widely used in mountainous terrain with steep slopes still questionable (Turnipseed et al. 2003; Cevik and Topal 2003). Some models, such as AGNPS or ANSWER, are unsuitable in Nepal due to large amounts of data and AGNPS, non-applicable to this Middle hill area (Kettner 1996; Ayalew 2020). On the other hand, modeling results are impressive but difficult to interpret and validate because of its complexity (Meyer and Flanagan 1992). Overall, such models include errors because they based on empirical rules. This model identifies areas at risk, where management actions needed (Rabia 2012; Roșca et al. 2012). It's simple, flexible, and physical base for predicting the relative soil loss pattern; however, the high hills are heterogeneous on precipitation patterns and topography. It assesses soil erosion accuracy estimates from the models using ground observations. It's impossible to validate the assessments and analyze error and bias by comparing model prediction with field-based measurements over a set of sites. There have been very few field-based studies in the area. However, the output compared with the estimated erosion levels of different studies from published articles and with other model-based results of mid and high hill areas in Nepal with similar characteristics to the Dolakha (Kebede 2001; Saxton and Rawls 2006).

The method contains limitations and potential for factors that drive erosion in the RUSLE model. Precipitation data from TRMM Data used for hill areas to calculate the rainfall erosion factor. Weather stations in the Himalayan region limited, and spatial precipitation data is low resolution. Furthermore, this approach is unable to capture the distribution of massive precipitation events, markedly impacting soil erosion. The cover management factor (C) and support practice factor (P) weighted at soil order level using published results (Uddin et al. 2018). Better estimates could determine the $\mathrm{C}$-factor by remote sensing, have used vegetation indices such as the Normalized Difference Vegetation 
Index (NDVI) (Almagro et al. 2019a, b). Usually, NDVI directly correlated to the C-factor by linear or exponential regression (Yue-Qing et al. 2008; Van der Knijff et al. 1999). An alternative approach for an approximation of the P-factor based on empirical equations. For instance, Wener's method assumes that the P-factor linked to topographical features, and slope gradient (Panagos et al. 2015; Terranova et al. 2009; Phinzi and Ngetar 2019). The RUSLE method reported overestimating erosion in high terrain (Ganasri and Ramesh 2016; Uddin et al. 2018). The Rich Mesic Forest (RMF) and Mesic Forest (MF) models better estimates over a slope with ground data (Fall et al. 2011; Bellemare et al. 2005). Comprehensive research appropriate for accurate estimation of erosion model and ground measurements.

\section{Conclusions}

The severity assessment of soil erosion GIS-based RUSLE equation considering rainfall, soil, DEM, land use, and land cover. The soil erosion rate categorized into six classes based on its severity, and $5.01 \%$ of the regions found under extreme risk $\left(>80 \mathrm{Mg} \mathrm{ha}^{-1}\right.$ year $\left.^{-1}\right)$ $70 \%$ of areas remained in a low-risk zone. This show area with high elevation along with prompt rainfall susceptible to soil erosion. The predicted severity can provide a basis for conservation and planning processes at the decision-makers. The regions with high to very severe soil erosion warrant special priority and control measures. While this model forms a basis on mapping and prediction using remote sensing and GIS-based analysis for vulnerability zones, such studies suggested for conservation and refining the model in the future.

\section{Abbreviations \\ RUSLE: Revised Universal Soil Loss Equation; ArcGIS: Arc Geographic Informa- tion System; DEM: Digital Elevation Model; SRTM DEM: Shuttle Radar Topog- raphy Mission, Digital Elevation Model; METI: Ministry of Economy, Trade and Industry, Japan; NASA: National Aeronautics and Space Administration, US; ICIMOD: International Center for Integrated Mountain Development; TRMM: Tropical Rainfall Measuring Mission; Yr:Year.}

\section{Acknowledgements}

I want to acknowledge the people who directly and indirectly contributed to the study.

\section{Authors' contributions}

The author has conducted all research activities such as data acquisition, analysis, evaluation, and result. The author read and approved the final manuscript.

\section{Funding}

No funding was received.

\section{Availability of data and materials}

The data used for this study mentioned with their sources; if data used in the manuscript are not precise, the author is ready to clarify and even send the dataset on request.
Ethics approval and consent to participant Not applicable.

\section{Consent for publication}

I agreed to submit the final manuscript for Environmental Systems Research Journal.

\section{Competing interests}

The author declares that they have no competing interests.

Received: 8 May 2020 Accepted: 13 July 2020

Published online: 18 July 2020

\section{References}

Almagro A et al (2019a) International soil and water conservation research Almagro A et al (2019b) Improving cover and management factor (C-factor) estimation using remote sensing approaches for tropical regions. Int Soil Water Conserv Res 7(4):325-334

Angima SD, Stott DE, O'neill MK, Ong CK, Weesies GA (2003) Soil erosion prediction using RUSLE for central Kenyan highland conditions. Agric Ecosyst Environ 97(1-3):295-308

Ashiagbor G, Forkuo EK, Laari P, Aabeyir R (2013) Modeling soil erosion using RUSLE and GIS tools. Int J Remote Sens Geosci 2(4):1-17

Assouline S, Ben-Hur M (2006) Effects of rainfall intensity and slope gradient on the dynamics of interrill erosion during soil surface sealing. CATENA 66(3):211-220

Atoma $\mathrm{H}$ (2018) Assessment of soil erosion by Rusle model using remote sensing and GIS techniques: a case study of Huluka Watershed, Central Ethiopia, PhD Thesis, Addis Ababa University

Ayalew M (2020) Evaluating the sediment yield by improving the RUSLE and SDR in Gumara Watershed, Upper Blue Nile Basin, Ethiopia, PhD Thesis

Bahadur KK (2012) Spatio-temporal patterns of agricultural expansion and its effect on watershed degradation: a case from the mountains of Nepal. Environ Earth Sci 65(7):2063-2077

Bakker MM, Govers G, Kosmas C, Vanacker V, Van Oost K, Rounsevell M (2005) Soil erosion as a driver of land-use change. Agric Ecosyst Environ 105(3):467-481

Bastola S, Seong YJ, Lee SH, Shin Y (2019) Assessment of soil erosion loss by using RUSLE and GIS in the Bagmati Basin of Nepal, 20(3):5-14

Bellemare J, Motzkin G, Foster DR (2005) Rich mesic forests: edaphic and physiographic drivers of community variation in western Massachusetts. Rhodora 107(931):239-283

Blaikie P, Brookfield H (2015) Land degradation and society. Routledge, London Boggs G, Devonport C, Evans K, Puig P (2001) GIS-based rapid assessment of erosion risk in a small catchment in the wet/dry tropics of Australia. Land Degrad Dev 12(5):417-434

Cevik E, Topal T (2003) GIS-based landslide susceptibility mapping for a problematic segment of the natural gas pipeline, Hendek (Turkey). Environ Geol 44(8):949-962

Chalise D, Kumar L, Spalevic V, Skataric G (2019) Estimation of sediment yield and maximum outflow using the IntErO model in the Sarada river basin of Nepal. Water 11(5):952

Ciesiolka CA et al (1995) Methodology for a multi-country study of soil erosion management. Soil Technol 8(3):179-192

Coughlan KJ, Rose CW (1997) A new soil conservation methodology and application to cropping systems in tropical steeplands: a comparative synthesis of results obtained in ACIAR Project PN 9201, ACIAR

Dennison L, Rana P (2017) Nepal's emerging data revolution. Development Initiatives, Washington

Erencin Z, Shresta DP, Krol IB (2000) C-factor mapping using remote sensing and GIS. Case study Lom SakLom Kao Thail Geogr Inst Justus-Liebig-Univ Giess Intern Inst Aerosp Surv Earth ScilTC Enschede Netherland

Erol A, Koşkan Ö, Başaran MA (2015) Socioeconomic modifications of the universal soil loss equation. Solid Earth 6:1025-1035

Fall S et al (2011) Analysis of the impacts of station exposure on the US Historical Climatology Network temperatures and temperature trends. J Geophys Res Atmos. https://doi.org/10.1029/2010JD015146 
Ganasri BP, Ramesh H (2016) Assessment of soil erosion by RUSLE model using remote sensing and GIS - a case study of Nethravathi Basin. Geosci Front 7(6):953-961

Gardner R, Jenkins A (1995) Land use, soil conservation and water resource management in the Nepal middle hills. Overseas Development Administration, London

Gorr WL, Kurland KS (2010) GIS tutorial 1: basic workbook. Esri Press, Redlands

Jha MK, Paudel RC (2010) Erosion predictions by empirical models in a mountainous watershed in Nepal. J Spat Hydrol 10(1):89-102

Kebede TA (2001) Farm household technical efficiency: a stochastic frontier analysis. Study Rice Prod Mardi Watershed West Dev Reg Nepal Masters Thesis Submitt Dep Econ Soc Sci Agric Univ Norway

Kettner A (1996) Simulated man-induced erosion in the Middle Mountains of Nepal, a case study on the relation between land use, land tenure and erosion with the use of the AGNPS-model in the Mahadev Khola watershed, PhD Thesis, Msc thesis (unpublished), Dept. of Soil and Water Conservation and...

Koirala P, Thakuri S, Joshi S, Chauhan R (2019) Estimation of soil erosion in Nepal using a RUSLE modeling and geospatial tool. Geosciences 9(4):147

Kouli M, Soupios P, Vallianatos F (2009) Soil erosion prediction using the revised universal soil loss equation (RUSLE) in a GIS framework, Chania, Northwestern Crete, Greece. Environ Geol 57(3):483-497

Kumar S, Kushwaha SPS (2013) Modelling soil erosion risk based on RUSLE-3D using GIS in a Shivalik sub-watershed. J Earth Syst Sci 122(2):389-398

Lu H, Prosser IP, Moran CJ, Gallant JC, Priestley G, Stevenson JG (2003) Predicting sheetwash and rill erosion over the Australian continent. Soil Res 41(6):1037-1062

Maetens W, Vanmaercke M, Poesen J, Jankauskas B, Jankauskiene G, Ionita I (2012) Effects of land use on annual runoff and soil loss in Europe and the Mediterranean: a meta-analysis of plot data. Prog Phys Geogr 36(5):599-653

Magdoff F, Weil RR (2004) Soil organic matter in sustainable agriculture. CRC Press, Boca Raton

McCool DK, Brown LC, Foster GR, Mutchler CK, Meyer LD (1987) Revised slope steepness factor for the universal soil loss equation. Trans ASAE 30(5):1387-1396

McCool DK, Foster GR, Mutchler CK, Meyer LD (1989) Revised slope length factor for the universal soil loss equation. Trans ASAE 32(5):1571-1576

Mekelle E (2015) Assessing Runoff and soil erosion by water using GIS and RS techniques at Midmar Catchment, Northern Ethiopia BY: Tsegay Aregawi Gebremedhn, PhD Thesis, Mekelle University

Meyer CR, Flanagan DC (1992) Application of case-based reasoning concepts to the WEPP soil erosion model, Al Appl USA

Milward A, Mersey JE (1999) Adapting the RUSLE to model soil erosion potential in a mountainous tropical watershade. Catena 38(2):109-129

Morgan RPC, Morgan DDV, Finney HJ (1984) A predictive model for the assessment of soil erosion risk. J Agric Eng Res 30:245-253

Morgan RPC, Quinton JN, Rickson RJ (1992) EUROSEM documentation manual. Silsoe Coll. Silsoe Bedford UK, p 34

Navas A, Garcés BV, Machín J (2004) Research Note: An approach to integrated assessment of reservoir siltation: the Joaquín Costa reservoir as a case study

Nearing MA, Pruski FF, O'neal MR (2004) Expected climate change impacts on soil erosion rates: a review. J Soil Water Conserv 59(1):43-50

Panagos P, Borrelli P, Meusburger K, Alewell C, Lugato E, Montanarella L (2015) Estimating the soil erosion cover-management factor at the European scale. Land Use Policy 48:38-50

Park C-S, Jung Y-S, Joo J-H, Lee J-T (2005) Best management practices reducing soil loss in the saprolite piled upland in Hongcheon highland. Korean J Soil Sci Fertil 38(3):119-126

Pei S, Sharma UR (1998) Transboundary biodiversity conservation in the Himalayas. Ecoregional Coop Biodivers Conserv Himalayas, 164-184

Phinzi K, Ngetar NS (2019) The assessment of water-borne erosion at catchment level using GIS-based RUSLE and remote sensing: a review. Int Soil Water Conserv Res 7(1):27-46

Pimentel D et al (1995) Environmental and economic costs of soil erosion and conservation benefits. Science 267(5201):1117-1123

Prasannakumar V, Vijith H, Abinod S, Geetha N (2012) Estimation of soil erosion risk within a small mountainous sub-watershed in Kerala, India, using Revised Universal Soil Loss Equation (RUSLE) and geo-information technology. Geosci Front 3(2):209-215
Rabia AH (2012) Mapping soil erosion risk using RUSLE, GIS and remote sensing techniques. In: The 4th international congress of ECSSS, EUROSOIL, Bari, Italy, pp 1-15

Ristić R, Kostadinov S, Radić B, Trivan G, Nikić Z (2012) Torrential floods in Serbia-man made and natural hazards. In: 12 th congress interpraevent

Roșca B, Vasiliniuc I, Topșa G (2012) Models for estimating soil erosion in the middle and lower vasluie\AA\pounds Basin. Bull Univ Agric Sci Vet Med Cluj-Napoca Agric, 69(1)

Samaras AG, Koutitas CG (2014) The impact of watershed management on coastal morphology: a case study using an integrated approach and numerical modeling. Geomorphology 211:52-63

Saxton KE, Rawls WJ (2006) Soil water characteristic estimates by texture and organic matter for hydrologic solutions. Soil Sci Soc Am J 70(5):1569-1578

Shah PB, Schreier H, Brown SJ, Riley KW (1991) Soil fertility and erosion issues in the middle mountains of Nepal: workshop proceedings, Jhikhu Khola Watershed, Apr 22-25, 1991

Shahid S (2013) Modelling soil erosion susceptibility of johor river basin by using geographical information system (GIS)

Sheikh Â AH, Palria S, Alam A (2011) Integration of GIS and universal soil loss equation (USLE) for soil loss estimation in a Himalayan watershed. Recent Res Sci Technol. https://doi.org/10.21203/rs.3.rs-25478/v2

Shrestha DP (1997) Assessment of soil erosion in the Nepalese Himalaya: a case study in Likhu Khola Valley, Middle Mountain Region. Land Husb 2(1):59-80

Stocking M (1984) Rates of erosion and sediment yield in the African environment. Chall Afr Hydrol Water Resour, 285-295

Suárez de Castro F, Rodríguez Grandas A (1962) Investigaciones sobre la erosión y la conservación de los suelos en Colombia [Research on soil erosion and conservation in Colombia]

Šúri M, Cebecauer T, Hofierka J, Fulajtár E (2002) Erosion assessment of Slovakia at regional scale using GIS. Ecology 21(4):404-422

Tadesse $L$ (2016) Assessing the impact of watershed development programs on soil erosion and biomass production using remote sensing and GIS: the case of Yezat Watershed, West Gojam Zone of Amhara Region, Ethiopia, PhD Thesis, Addis Ababa University

Tamene L, Vlek PL (2008) Soil erosion studies in northern Ethiopia. In: Land use and soil resources, Springer, pp 73-100

Tang Q, Xu Y, Bennett SJ, Li Y (2015) Assessment of soil erosion using RUSLE and GIS: a case study of the Yangou watershed in the Loess Plateau, China. Environ Earth Sci 73(4):1715-1724

Terranova O, Antronico L, Coscarelli R, laquinta P (2009) Soil erosion risk scenarios in the Mediterranean environment using RUSLE and GIS: an application model for Calabria (southern Italy). Geomorphology 112(3-4):228-245

Thapa P, Dhulikhel N (2019) Observed and perceived climate change analysis in the Terai Region, Nepal. GSJ 7(12)

Thapa P, Upadhyaya PS (2019) Vulnerability assessment of indigenous communities to climate change in Nepal

Thapa P, Upadhyaya PS (2020) Riverbed water extraction and utilization of Rural Communities Kavre, Nepal. Int Eur Ext Enablement Sci Eng Manag. (IEEE-SEM) 8(1):8-11

Tolllrism M (1995) Carrying capacity of Himalayan

Turnipseed AA, Anderson DE, Blanken PD, Baugh WM, Monson RK (2003) Airflows and turbulent flux measurements in mountainous terrain: part 1. Canopy and local effects. Agric For Meteorol 119(1-2):1-21

Uddin K, Abdul Matin M, Maharjan S (2018) Assessment of land cover change and its impact on changes in soil erosion risk in Nepal. Sustainability 10(12):4715

Van der Knijff JMF, Jones RJA, Montanarella L (1999) Soil erosion risk assessment in Italy. Citeseer

Vanacker V, Govers G, Barros S, Poesen J, Deckers J (2003) The effect of shortterm socio-economic and demographic change on landuse dynamics and its corresponding geomorphic response with relation to water erosion in a tropical mountainous catchment, Ecuador. Landsc Ecol 18(1):1-15

Wang G, Gertner G, Singh V, Shinkareva S, Parysow P, Anderson A (2002) Spatial and temporal prediction and uncertainty of soil loss using the revised universal soil loss equation: a case study of the rainfall-runoff erosivity $R$ factor. Ecol Model 153(1-2):143-155 
Wang L, Huang J, Du Y, Hu Y, Han P (2013) Dynamic assessment of soil erosion risk using Landsat TM and $\mathrm{HJ}$ satellite data in Danjiangkou Reservoir area, China. Remote Sens 5(8):3826-3848

Wischmeier WH, Smith DD (1978) Predicting rainfall erosion losses: a guide to conservation planning. Department of Agriculture, Science and Education Administration, Indiana

Yitayew M, Pokrzywka SJ, Renard KG (1999) Using GIS for facilitating erosion estimation. Appl Eng Agric 15(4):295

Yue-Qing X, Xiao-Mei S, Xiang-Bin K, Jian P, Yun-Long C (2008) Adapting the RUSLE and GIS to model soil erosion risk in a mountains karst watershed, Guizhou Province, China. Environ Monit Assess 141(1-3):275-286
Zhao G, Mu X, Wen Z, Wang F, Gao P (2013) Soil erosion, conservation, and eco-environment changes in the Loess Plateau of China. Land Degrad Dev 24(5):499-510

\section{Publisher's Note}

Springer Nature remains neutral with regard to jurisdictional claims in published maps and institutional affiliations.

\section{Submit your manuscript to a SpringerOpen ${ }^{\circ}$ journal and benefit from:}

- Convenient online submission

- Rigorous peer review

- Open access: articles freely available online

- High visibility within the field

- Retaining the copyright to your article

Submit your next manuscript at $\boldsymbol{\nabla}$ springeropen.com 